\title{
Fuzzy modelling of slope erosion by runoff. Case study in Corinth basin, Greece
}

\author{
Niki EVELPIDOU ${ }^{1 *}$, Theodoros GOURNELOS ${ }^{1}$, Eirini KARDARA ${ }^{1}$, Anna KARKANI ${ }^{1}$ \\ ${ }^{1}$ Faculty of Geology and Geoenvironment, National and Kapodistrian University of Athens, \\ Panepistimiopolis 15784, Athens, Greece
}

Received 5 August 2018; Revised 10 November 2018; Accepted 1 December 2018

*Correspondence to: Niki EVELPIDOU, e-mail: evelpidou@geol.uoa.gr

\begin{abstract}
This research applies the fuzzy set theory via Geographical Information Systems (GIS) - based analysis, in order to model slope erosion by runoff. For this purpose, the following steps were accomplished: definition of input variables (rocks' susceptibility to erosion, slope inclination, slope morphology), development of a fuzzy inference system based on theoretical and empirical knowledge, transformation of input to output variables (erosion - deposition) and visualization of the output variables (spatial distribution of erosion-deposition processes). The method was applied on the drainage basin of Corinth, located in the north-eastern part of Peloponnese (Greece), where a series of catastrophic erosional events have recently occurred.
\end{abstract}

KEYWORDS

fuzzy modelling; slope erosion; GIS-based analysis; Greece

\section{Introduction}

Erosion rates depend on a variety of factors, such as the frequency and magnitude of precipitation, surface and subsurface waters, slope morphology (length and inclination), rock's susceptibility to erosion, land use and human impacts.

The amount and intensity of precipitation control surface and subsurface runoff. Splash erosion by raindrop impact results in the breaking and detachment of soil particles. In addition, slope char- acteristics have a significant role. Sediment removal is estimated as a function of distance to divide multiplied by a power of slope gradient (Kirkby, 1978). Rock composition and texture, expressed as physical resistance, can further affect erosion rates (Meybeck, 1987).

The vegetative cover acts as a protective mechanism to the weathering material by reducing the energy of rain, but also controls the soil and the 
weathering mantle thickness and, consequently infiltration.

The increasing human interventions to the environment have contributed to the acceleration of erosion processes, for instance with frequent forest fires and urban expansion. Human interventions also control the vegetative cover, through the management of cultivated areas and pasture lands (Evelpidou et al., 2018). Moreover, changes in land use, such as expanding agricultural land and deforestation, have made the weathering products more vulnerable to erosion. In terms of runoff erosion, three factors of land use are critical, the vegetative cover and its role, the surface cap and the mechanical disturbance of the soil (Wischmeier, 1975; Renard et al., 1997; Weltz et al., 1998).

Another important variable that needs to be taken into account is climate change and its causes. The International Panel on Climate Change (IPCC) has predicted frequent and severe droughts and floods caused by irregular climatic conditions in the future, making water resources management difficult (Ahn et al., 2018).

Runoff may be expressed as sheets of water or as small rills; its eroding capacity being related to the vegetative cover and it is expected to gradually increase downslope (Langbein and Schumm, 1958). During heavy precipitations, gullies tend to grow in depth and upslope. This process leads to the expansion of the drainage basin. The transported material can be deposited in the low catchment areas or may end up in a stream channel. This highlights the close interrelations of stream and slope evolution.

Weathering and erosion processes are also closely interrelated. The weathering mechanism produces new material, while erosional processes transport the material to the lower parts of the drainage basin. Erosion is active, as long as surface deposits are present, and when the whole waste mantle is removed, erosion agents become inactive. This mass balance (Ahnert, 1987) controls the spatial distribution of the denudation weathering-limited and denudation transport-limited areas in the drainage basins (Young, 1972; Chorley et al., 1984). It is noted that in slope hollows, the material is slowly transported downwards by creep processes, while rapid mass movements act as coupling points by removing the material (Ahnert, 1996; Selby and Hodder, 2000). According to Wolka et al. (2015), the combination of steep slope, low vegetation cover, along with erosive rainfall or extreme weather conditions, induces a non-tolerable soil erosion problem. Therefore, erosion risk mitigation strategies should focus on the protection of steep slope areas.

In this context, the aim of this paper is to study the dynamic processes of erosion by mapping zones of different erosion degree and deposition in a holistic approach. This mapping is related to practical problems caused by nowadays erosion events, and its scope is formulating measures to stop or limit flow concentration and minimize erosional events (Kirkby, 1978). Nowadays several models have been developed for mapping erosion, however there is a lack of precise methods of monitoring. Traditional field-based methods of monitoring erosion (sediment traps, erosion pins, and bridges) can be labour intensive and therefore are generally limited in spatial intensity and/or extent (Gillan et al., 2016). Therefore, this work also aims to stimulate the necessity of developing a long-term monitoring mechanism for the repeated floods and soil erosion events in order to protect environmental deterioration.

\section{Regional setting}

The study area, the drainage basin of Corinth, is located in the north-eastern part of Peloponnese (Fig. 1). This area was chosen as a case study mainly because it is dominated by vulnerable rocks prone to erosion, and, because catastrophic floods accompanied by vast erosion occurred recently (1997) and are expected to happen again.

The drainage basin of Corinth is characterized by a low-lying coastal area in the northern part and a hilly and semi-mountainous area in the south. The area is mainly composed of Quaternary and Neogene formations at the northern part and limestones of Alpine age at the south. The Neogene formations consist mainly of alterations of marls, sandstones, conglomerates, limestones, etc. (Bornovas et al., 1972). The drainage system of Corinth is characterized by an elongated basin, of a northsouth direction, with a dendritic form. The form and 
size of the drainage system are related to the topographic, geological and hydrological parameters.

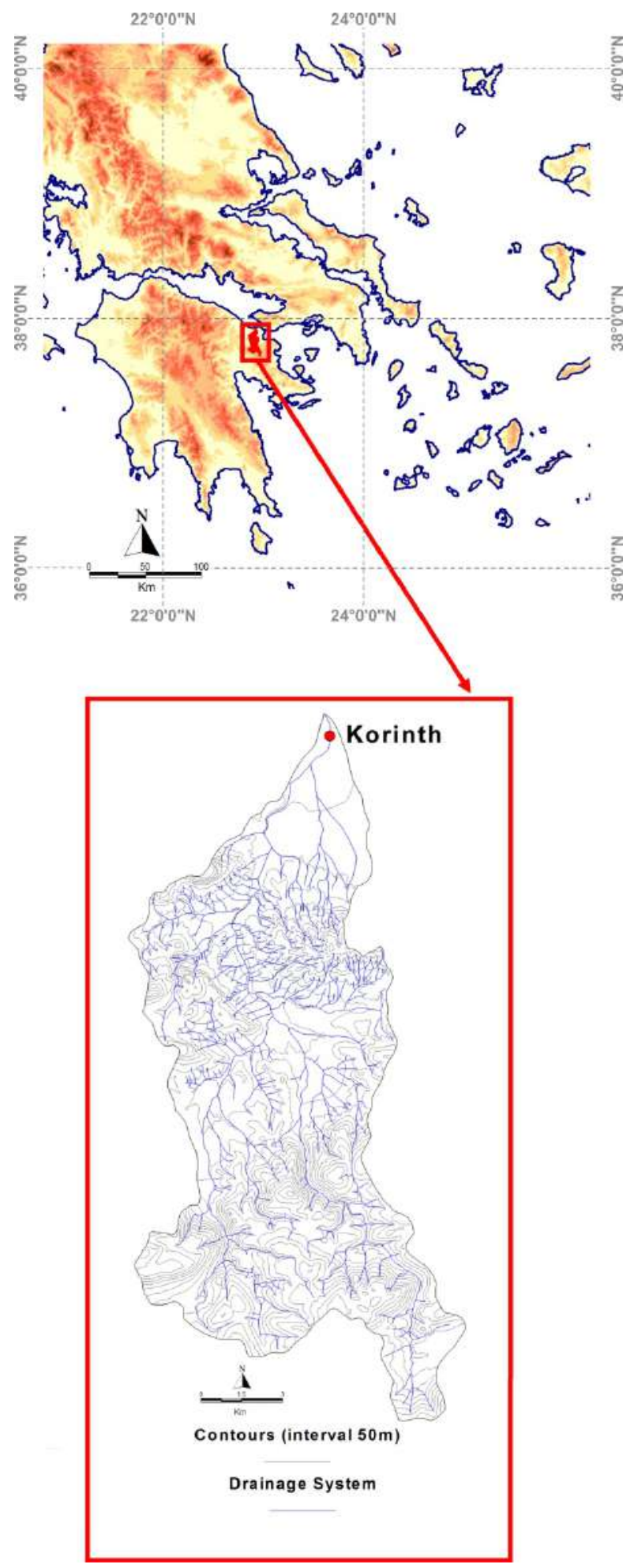

Figure 1 Location of the study area

\section{Methodology}

The study of erosional processes demands a series of steps in order to obtain the final output maps. These steps include (Fig. 2): 1) field-work, interpretation of aerial photos and satellite images, development of a GIS database with geological, topographical and drainage data), 2) definition of input and output variables, 3) formulation of appropriate logical rules (boolean or fuzzy) for the transformation of input to output variables, 4) analysis and visualization of the output results.

For this work, the input variables used were susceptibility of rocks to erosion, slope inclination and slope morphology. The output was the erosion deposition variable. In previous research, Gournelos et al. $(2002,2004)$ have proposed an empirical way to estimate the rock's susceptibility to erosion. The susceptibility of rocks depends on a number of variables, with spatial and temporal variation. Firstly, it depends on the physical and chemical characteristics of the rocks. Thus, mineral composition is the determining factor for chemical weathering. Olivine, augite, hornblende, biotite and dark-colored minerals in general are more susceptible to weathering processes than orthoclase, muscovite, quartz and other light-coloured minerals (Sparks, 1965). Secondly, it depends on the presence of a protective vegetative cover, which contributes to the increase of the infiltration capacity and limits runoff. In general, the grain's form and size define permeability of rocks and, consequently, they control the time of water saturation and the initiation of runoff. Three categories of permeability values may be distinguished: very low (10-12 - 10-8 m/s), low to medium $(10-8-10-5 \mathrm{~m} / \mathrm{s})$ and high $(10-5-10-2 \mathrm{~m} / \mathrm{s})$ (Bolton, 1979). Thirdly, it depends on the characteristics of the involved processes: the intensity and duration of precipitation, its spatial and temporal distribution and the raindrop size. Susceptibility of rocks to erosion is difficult to be directly measured. There are some observations concerning either rock resistance to abrasion (Kuenen, 1956) or mass strength classification (Selby, 1987). The first attempt to assign susceptibility values to various rock types was made by Jensen and Painter (1974). 
The second processed variable was slope gradi- there is a linear or power relation between slope ent/inclination. When slopes are steeper, both the gradient and erosional products (Hack and Goodlett, gravitational movement and downslope sediment 1960; Schumm, 1977; Kirkby, 1969, 1978, 1995). delivery are higher. It has been noted that, in general,

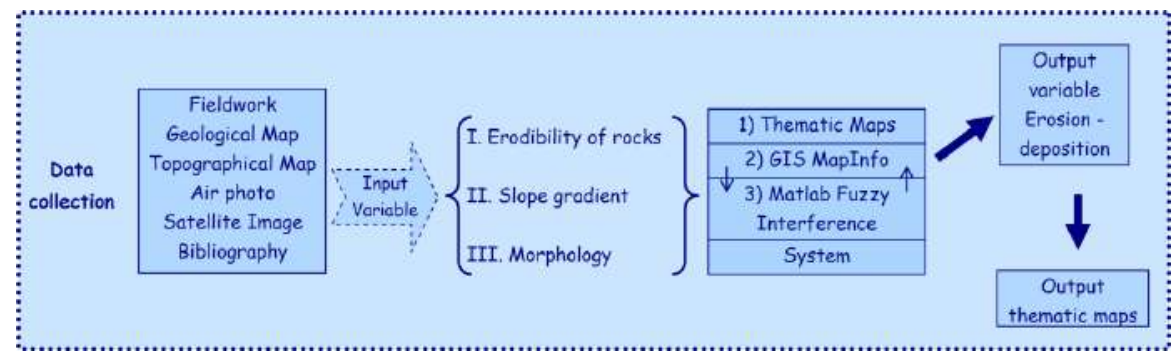

Figure 2 Flow diagram of the methodology followed in this work

The last input variable, slope morphology, is used to reflect the slope form (convex, concave, straight), the slope surface roughness and vegetative cover, the relation (transition) of a certain slope segment to upslope and downslope elements; in total, it defines the degree of the dominant erosional or depositional processes.

A large database was developed based on data derived from fieldwork and existing maps. In order to process different data sets, all input data were normalized. The entire original dataset was normalized by dividing them by their maximum value, in order to facilitate the comparison of data layers. The input variables (rocks' susceptibility to erosion, slope gradient and morphology) were treated as fuzzy ones (Zadeh, 1965, 1987; Yager et al., 1987; Dubois and Prade, 1980; Zimmermann, 1991; Klir and Yuan, 1995) assigning them the proper membership functions (Fig. 3).

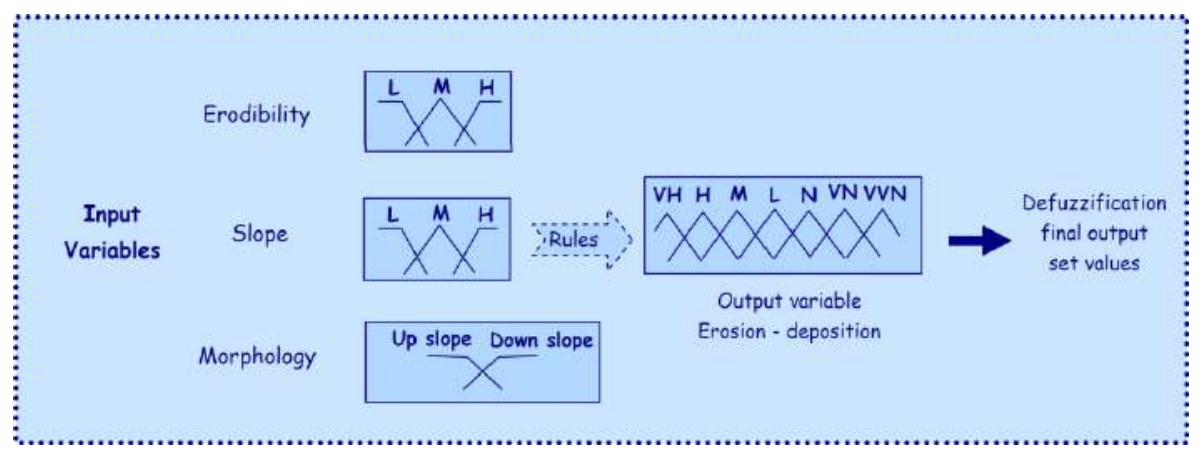

Figure 3 Flow diagram of the form of the membership functions of the input and output variables

The next step was to construct a fuzzy inference system transforming input to output variable (erosion-deposition variable). This was achieved by the formulation of the proper conditional rules based on theoretical as well as empirical knowledge of the erosional processes (Table 1 ).

The implementation of all the aforementioned procedures was achieved, firstly, by using the GIS MapInfo platform for the analysis and visualization of the input and output variables and, secondly, by using the MATLAB software package to construct the fuzzy inference mechanism based on Mamdani methodology (Mamdani and Assilian, 1975). The output variable, erosion, expresses the degree of erosion and deposition on the drainage basin. This variable is also of a fuzzy nature. The output variables have been subjected to centroid defuzzification mechanism in order to obtain the final non-fuzzy set of values. The first variable, rock's susceptibility to erosion, is closely related to the lithology. Limestones are characterized by high permeability values and are the oldest and hardest rocks in the drainage basin. Their relief is relatively higher in comparison to the northern Neogene and Quaternary formations. 
Fuzzy modelling of slope erosion by runoff. Case study in Corinth basin, Greece

Table 1 The fuzzy logical rules transforming input variables to the output one

\begin{tabular}{|c|c|c|c|c|c|c|}
\hline If Erodibility Is Low or Slope Is Low & $\&$ & $\begin{array}{l}\text { Morphological } \\
\text { Factor }\end{array}$ & Is Upslope & $\rightarrow$ & $\begin{array}{l}\text { Erosion } \\
\text { Risk }\end{array}$ & Is Low \\
\hline If Erodibility Is Medium \& Slope Is Medium & $\&$ & $\begin{array}{l}\text { Morphological } \\
\text { Factor }\end{array}$ & Is Upslope & $\rightarrow$ & $\begin{array}{l}\text { Erosion } \\
\text { Risk }\end{array}$ & Is Medium \\
\hline $\begin{array}{l}\text { If Erodibility Is High \& Slope Is Medium or } \\
\text { Vulnerability Is Medium \& Slope Is High }\end{array}$ & $\&$ & $\begin{array}{l}\text { Morphological } \\
\text { Factor }\end{array}$ & Is Upslope & $\rightarrow$ & $\begin{array}{l}\text { Erosion } \\
\text { Risk }\end{array}$ & Is High \\
\hline If Erodibility Is High \& Slope Is High & $\&$ & $\begin{array}{l}\text { Morphological } \\
\text { Factor }\end{array}$ & Is Upslope & $\rightarrow$ & $\begin{array}{l}\text { Erosion } \\
\text { Risk }\end{array}$ & Is Very High \\
\hline If Erodibility Is High \& Slope Is High & $\&$ & $\begin{array}{l}\text { Morphological } \\
\text { Factor }\end{array}$ & Is Downslope & $\rightarrow$ & $\begin{array}{l}\text { Erosion } \\
\text { Risk }\end{array}$ & Is Negative \\
\hline If Erodibility Is Low or Slope Is Low & $\&$ & $\begin{array}{l}\text { Morphological } \\
\text { Factor }\end{array}$ & Is Downslope & $\rightarrow$ & $\begin{array}{l}\text { Erosion } \\
\text { Risk }\end{array}$ & Is Very Negative \\
\hline $\begin{array}{l}\text { If Erodibility Is High \& Slope Is Medium or } \\
\text { Vulnerability Is Medium \& Slope Is High }\end{array}$ & \& & $\begin{array}{l}\text { Morphological } \\
\text { Factor }\end{array}$ & Is Downslope & $\rightarrow$ & $\begin{array}{l}\text { Erosion } \\
\text { Risk }\end{array}$ & Is Very Negative \\
\hline If Erodibility Is Medium \& Slope Is Medium & \& & $\begin{array}{l}\text { Morphological } \\
\text { Factor }\end{array}$ & Is Downslope & $\rightarrow$ & $\begin{array}{l}\text { Erosion } \\
\text { Risk }\end{array}$ & $\begin{array}{l}\text { Is Very-Very } \\
\text { Negative }\end{array}$ \\
\hline
\end{tabular}

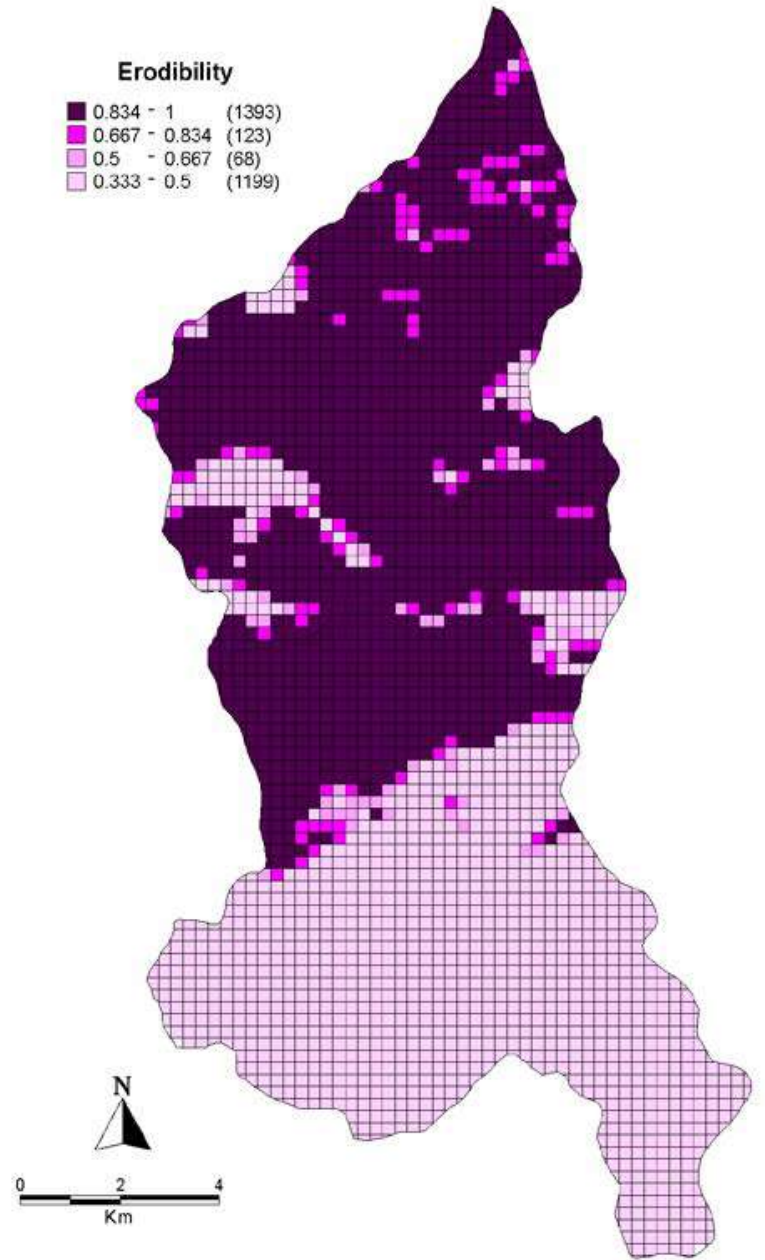

Figure 4 Spatial distribution of rocks' susceptibility to erosion variable of Corinth's drainage basin. The numbers in the brackets represent the frequency of each value range (number of grid cells belonging to the value range)

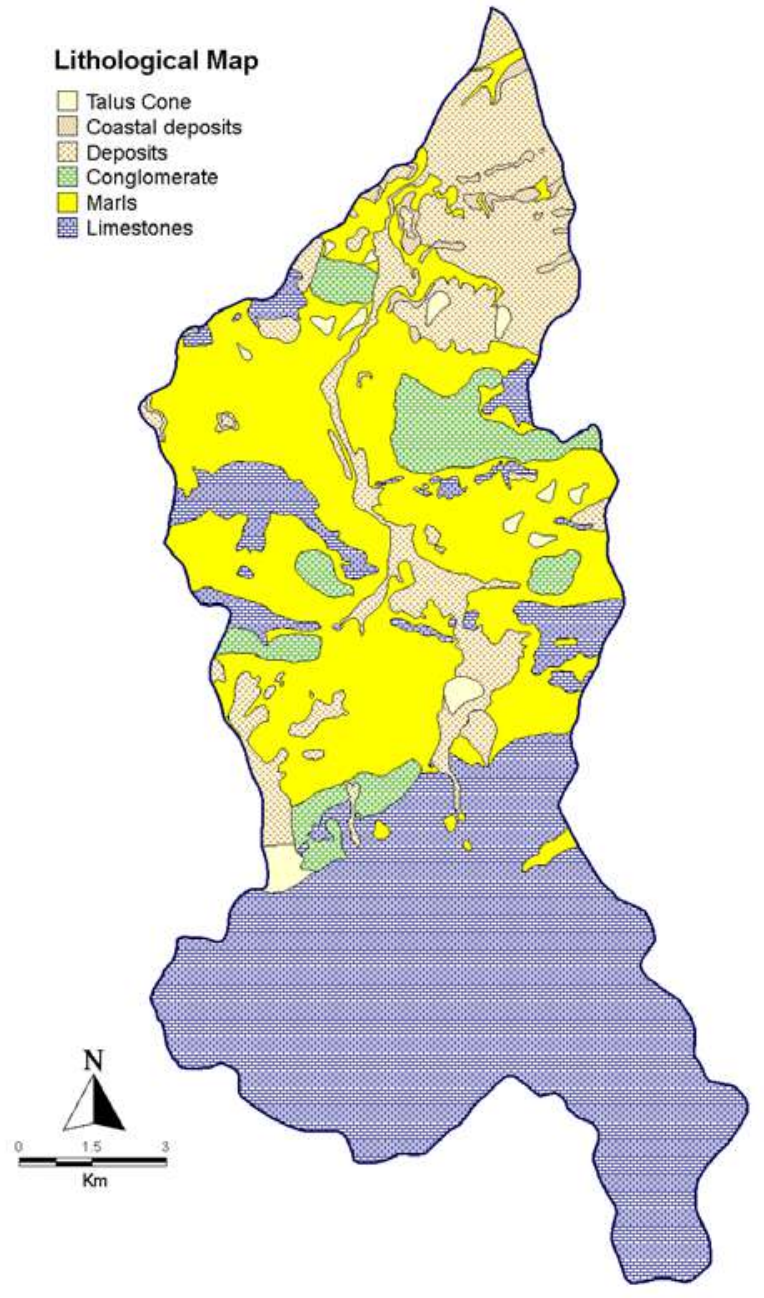

Figure 5 Lithological map of the drainage basin of Corinth 
Their relief is relatively higher in comparison to the northern Neogene and Quaternary formations. However, even in the latter group of sediments there are beds of different resistance to erosion and also lithological contrasts within the same bed formations. Conglomerates and sandstones are affected by chemical weathering, when cemented with calcium carbonate or iron oxides. Clays and shales are very susceptible to physical weathering due to the presence of primary or secondary discontinuities and their ability to absorb water (Sparks, 1965).

Three fuzzy classes were assigned to the rocks' susceptibility to erosion for the Corinth drainage

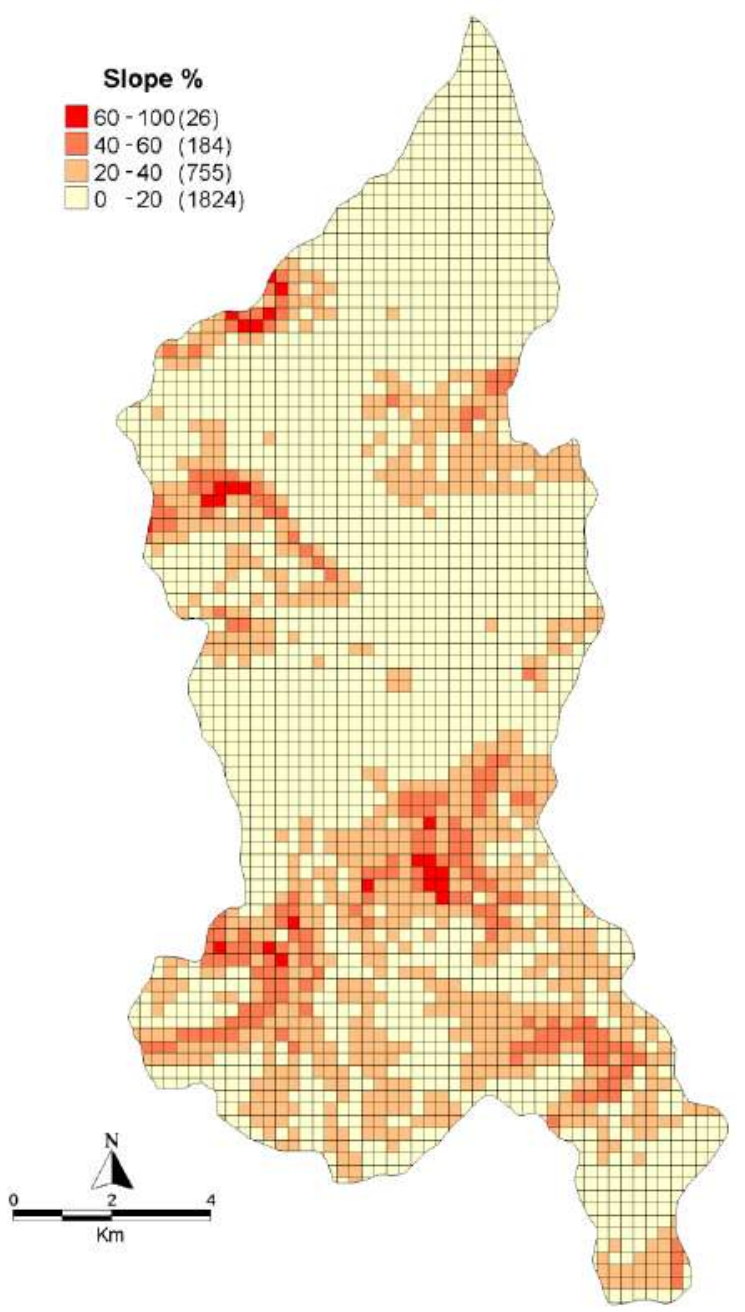

Figure 6 Spatial distribution of the slope gradient variable of Corinth drainage basin. The numbers in the brackets represent the frequency of each value ranges (number of grid cells belonging to the value range) basin, corresponding to the linguistic terms of 'low' $(0,0.5)$, 'medium' $(0.25,0.75)$ and 'high' $(0.5,1)$ susceptibility (Fig. 4). These represent the alpine limestones, resistant beds of Neogene formations and marls, sandstones and Quaternary sediments, respectively (Fig. 5).

The second processed variable was slope gradient (slope form and the predominant erosion or deposition processes), which has been calculated from the digital elevation model. In a similar way, three fuzzy classes have been assigned to slope variable: low, medium and high (Fig. 6).

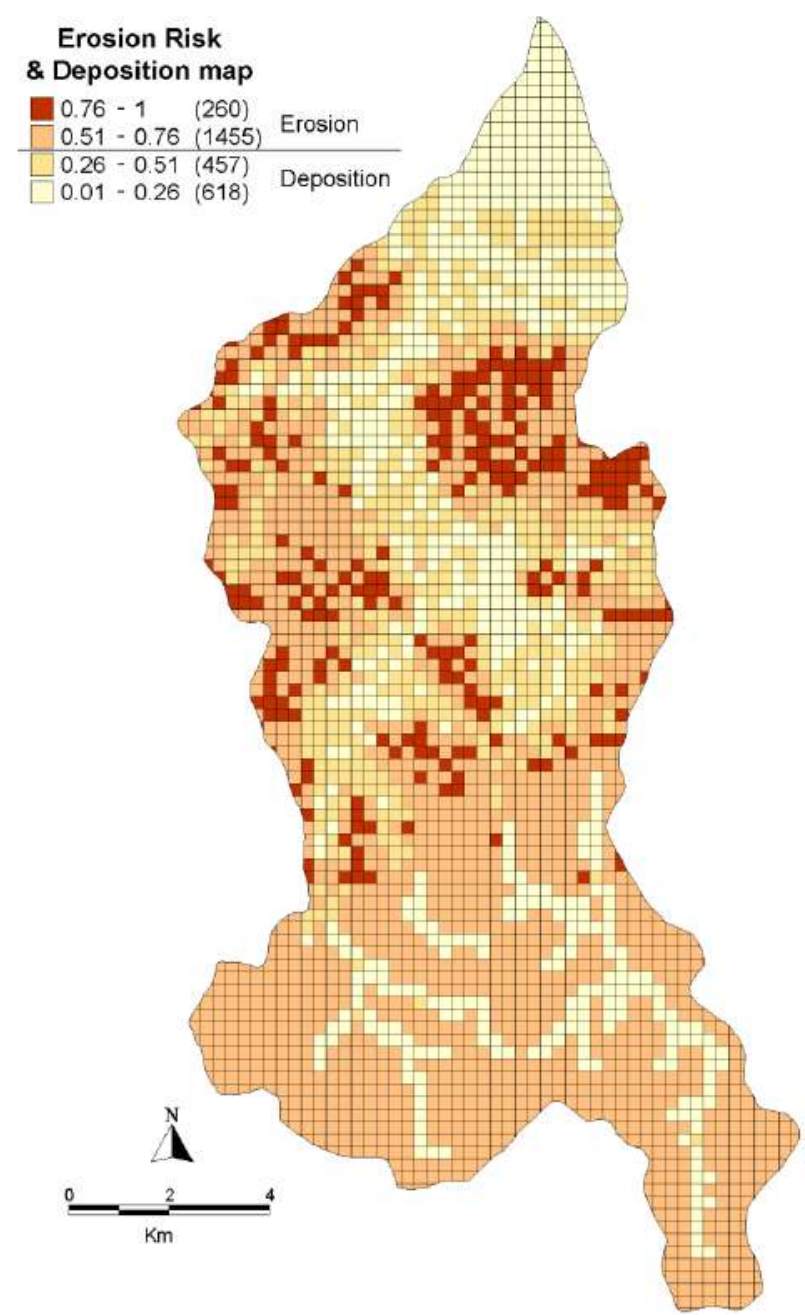

Figure 7 Spatial distribution of erosion - deposition of Corinth drainage basin. The erosion and deposition terms in the legend includes all the grades of this variable as defined in the text and figures. The numbers in the brackets correspond to the frequency of each value range (number of grid cells belonging to the value range) 
Slope morphology was the third variable. Apart from the slope gradient, the convex or concave form of the slope, the aspect and the total length of the slope are also very important factors. This variable has two fuzzy classes of values: the upslope and the downslope. Thus, values of $0.6-1$ represent convex slope forms, where deposition-limited processes are mainly present, while values of $0-0.6$ signify erosion - limited processes domination. The output variables were the erosion-deposition of fuzzy values and take the linguistic terms: Very High, High, Medium, Low, Negative, Very Negative, and Very-Very Negative (Table 1).

Finally, a sensitivity analysis was accomplished on the proposed model, through minimal modifications of the input variables, and the results (outputs) of this process have shown no significant changes to the expected values.

\section{Discussion}

The main disadvantage of erosion risk maps is that they reflect a static situation, which may change over time; even more importantly is the fact that the deposition-dominated areas are not mapped. Precipitation of variable intensity and duration may produce different erosional events and each erosional event is composed of erosional and depositional zones.

Climate change and extreme weather events call for the development of relatively simple methods to identify various natural hazards, globally; there is therefore need to predict areas of extensive soil erosion using real-world, input data at low cost with considerable accuracy (e.g. Mitra et al., 1998). A holistic approach was applied in this work, by mapping zones of different degree of erosion and deposition. This mapping is related to practical problems caused by contemporary erosional events and it may be used to formulate a series of suitable management solutions in order to avoid or diminish flow concentration and minimize erosional events (Kirkby, 1978).

It should be noted that recent erosion studies have been undertaken in the Mediterranean area (Onori et al., 2006; Ozcan et al., 2008) and new techniques have been proposed to evaluate erosion rates (Wang et al., 2008).
In the case of the drainage basin of Corinth, the resulting map (output variables) is shown in Fig. 7. This is a fuzzy-based approach of the main erosion and deposition zones of the study area.

It is clear that erosion occurs in upslope areas where Neogene or Quaternary formations are mainly present, while deposition occurs in the low flat areas close to the foot slope and the main drainage system. The aforementioned results have been further confirmed through field observations in the study area. This spatial distribution of erosion and deposition zones explains the recent catastrophic flooding of Corinth city, situated in the northern part of the drainage basin. It must be noted that recently, on 11th February 2007, this drainage basin has suffered another flooding event followed by widespread erosion, confirming our estimation about the response of this system to high precipitation.

\section{Conclusions}

This paper focused on a fuzzy based methodology through GIS based analysis for studying runoff erosion risk, which obliterates the main disadvantage of erosion risk maps reflecting a static situation. The methodology was applied in Corinth drainage basin, and our results were confirmed by field data.

The resulting map of the proposed methodology is a fuzzy-based approach of the main erosional and depositional zones of the drainage basin of Corinth. This methodology is relatively simple to implement using a GIS platform and it could be used together with a long-term monitoring mechanism for the repeated floods and soil erosion events in order to prevent from environmental issues as well as economic losses.

\section{References}

Ahn JM, Kwon HG, Yang DS, Kim YS. 2018. Assessing environmental flows of coordinated operation of dams and weirs in the Geum River basin under climate change scenarios. Science of The Total Environment, 643: 912-925. DOI: 10.1016/j.scitotenv.2018.06.225

Ahnert F. 1987. Process - response models of denudation at different spatial scales. Catena Supplement, 10: 3150. 
Ahnert F. 1996. Introduction to Geomorphology. Arnold, $352 \mathrm{p}$.

Bolton M. 1979. A Guide to soil mechanics. McMillan, London, $448 \mathrm{p}$.

Bornovas J, Lalechos N, Filippakis N. 1972. Ingenieurs Geologues de E.N.S.P.M. de l'institut Francais de Petrole. IGME, Athens.

Chorley RJ, Schumm SA, Sugden DE. 1984. Geomorpho/ogy. Mehuen, London.

Dubois D, Prade H. 1980. Fuzzy Sets and Systems Theory and Applications. Academic Press, New York.

Evelpidou, N, Kampolis, I, Karkani, A. 2018. Geomorphic Features Associated with Erosion. In: Singh R, Bartlett D. (eds.): Natural Hazards Earthquakes, Volcanoes, and Landslides. CRC Press-Taylor \& Francis, Boca Raton, 205-231.

Gillan JK, Karl JW, Barger NN, Elaksher A, Duniway MC. 2016. Spatially Explicit Rangeland Erosion Monitoring Using High-Resolution Digital Aerial Imagery. Rangeland Ecology \& Management, 69(2): 95-107. https://doi.org/10.1016/j.rama.2015.10.012

Gournelos Th, Vassilopoulos A, Evelpidou N. 2002. Erosional processes in the north-eastern part of Attika (Oropos coastal zone) using web-GIS and soft computing technology. Proceedings of the 3rd International conference on Risk Analysis, Sintra, Portugal, 19-21 June. WIT press 3: 416-424.

Gournellos Th, Evelpidou N, Vassilopoulos A. 2004. Developing an Erosion risk map using soft computing methods (case study at Sifnos island). Natural Hazards $\mathbf{3 1}$ (1): 39-61.

Hack JT, Goodlett JC. 1960. Geomorphology and forest ecology of a mountain region in the central Appalachians. U.S. Geol. Survey, 347, 66p.

Jensen JM, Painter RB. 1974. Predicting sediment yield from climate and topography. Journal of Hydrology, 21:371-380.

Kirkby MJ. 1969. Infiltration, through flow and overland flow. In: Chorley RJ (ed.): Water, Earth and Man. Methuen, London, 215-227.

Kirkby MJ.1978. Implications for sediment transport. In: Kirkby MJ (ed.): Hillslope Hydrology. John Wiley, Chichester, 325-340.

Kirkby MJ. 1995. Modelling the links between vegetation and landforms. Geomorphology, 13: 319-335.

Klir GJ, Yuan B. 1995. Fuzzy Sets and Fuzzy Logic theory and applications. Prentice - Hall, New Jersey.

Kuenen PH. 1956. Rolling by current (Pt) 2 of Experimental abrasion of pebbles. Journal of Geology, 64: 336-368.

Langbein WB, Schumm SA. 1958. Yield of sediment in relation to mean annual precipitation. Transactions American Geophysical Union, 39: 1076-84.
Mamdani EH, Assilian S. 1975. An experiment in linguistic synthesis with a fuzzy logic controller. International Journal of Man-Machine Studies, 7(1):1-13.

Meybeck M. 1987. Global chemical weathering of surficial rocks estimated from river dissolved loads. American Journal of Science, 287: 401-28.

Mitra B, Scott HD, Dixon JC, McKimmey JM. 1998. Applications of fuzzy logic to the prediction of soil erosion in a large watershed. Geoderma, 86(3-4): 183-209.

Onori F, Bonis de P, Grauso S, E.N.E.A, 2006. Italian National Agency for New Technologies, Energy and the Environment, Environmental Protection and Technologies Division Soil erosion prediction at the basin scale using the revised universal soil loss equation (RUSLE) in a catchment of Sicily (southern Italy). Environmental Geology International Journal of Geosciences, 50: 1129-1140.

Ozcan A, Erpul G, Basaran M, Erdogan E. 2008. Use of USLE/GIS technology integrated with geostatistics to assess soil erosion risk in different land uses of Indagi mountain pass-Cankiri, Turkey. Environmental Geology International Journal of Geosciences 53: 1731-1742.

Renard KG, Foster GR, Weesies GA, McCool DK, Yoder DC. 1997. Predicting Soil Erosion by Water: A Guide to Conservation Planning with the Revised Universal Soil Loss Equation (RUSLE). USDA Agricultural Handbook 703. U.S. Government Printing Office, Washington, DC.

Schumm SA. 1977. The fluvial system. Wiley, New York, $338 \mathrm{p}$.

Selby MJ. 1987. Rock slopes. In: Anderson MG, Richards KS. (eds.): Slope Stability. Wiley, Chichester, 475-504.

Selby MJ, Hodder APW. 2000. Hillslope materials and processes. 2nd edition, Oxford University Press, USA, $451 \mathrm{p}$.

Sparks BW. 1965. Geomorphology. Longmans UK, 371 p.

Yager RR, Ovchinnikov S, Tong RM, Nguyen HT. 1987. Fuzzy Sets and Applications. Wiley, New York.

Young A. 1972. Slopes. Oliver \& Boyd, Edinburgh, 288 p.

Zadeh LA. 1965. Fuzzy sets. Information and Control, 8: 338-353.

Zadeh LA. 1987. The concept of linguistic variable and its application to approximate reasoning. In: Yager, RR Ovchinnikov S, Tong RM, Nguyen HT. (eds.): Fuzzy Sets and Applications. Wiley, New York, 293-329.

Zimmermann HJ. 1991. Fuzzy Set Theory and Its Application. 2nd edition, Springer, Dordrecht.

Wang Y, Wang G, Hu H, Cheng H. 2008. Erosion rates evaluated by the $137 \mathrm{Cs}$ technique in the high altitude area of the Qinghai - Tibet plateau of China. Environmental Geology International Journal of Geosciences, 53: 1743-1749.

Weltz MA, Kidwell MR, Fox HD. 1998. Influence of abiotic and biotic factors in measuring and modelling soil ero- 
sion on rangelands: State of knowledge. Journal of Range Management, 51: 482-495.

Wischmeier WH. 1975. Estimating the soil loss equation's cover and management factor for undisturbed areas. In: Present and Prospective Technology for Predicting Sediment Yields and Sources. USDA Agricultural Re- search Service ARS-S-40. USDA Science and Education Administration, Washington DC, 118-124.

Wolka K, Tadesse H, Garedew E, Yimer F. 2015. Soil erosion risk assessment in the Chaleleka wetland watershed, Central Rift Valley of Ethiopia. Environmental Systems Research 4: 5. DOI: 10.1186/s40068-015-0030-5. 